calibrating the Eyetone was perhaps a significant factor in our patient's choice. For hospital use a mains-operated monitor is usually desirable. Our electronics engineer gave marginal preference for Eyetone. Reflomat, however, has a potential advantage in that the Reflotest system holds its colour and reading, which could be an advantage under certain circumstances. ${ }^{4}$ Both the Eyetone and the Reflomat gave good results. Our experience with Eyetone monitors over several years has been favourable and the after-sales service excellent.

For self-monitoring, however, further advances in technology are expected. The BM-Test-Glycemie $20-800$ strip (Boehringer) now available is yielding encouraging results and may provide a system of monitoring without the need for an actual monitor. Nevertheless, of the four monitors currently available our triple assessment of patient preference, laboratory performance, and electronic opinion gave first place to Hypocount.
We acknowledge the help and encouragement of the British Diabetic Association and the helpful co-operation of the Ames, Boehringer, Hypoguard, and Medistron companies.

\section{References}

${ }^{1}$ Sönksen PH. Home-monitoring of blood glucose. British Diabetic Association-Clinic Newsletter. June 1979:4-7.

2 Sönksen PH, Judd SL, Lowy C. Home monitoring of blood-glucosemethod of improving diabetic control. Lancet 1978; :729-32.

${ }^{3}$ Walford S, Allison SP, Gale EAM, Tattersall RB. Self-monitoring of blood-glucose-improvement of diabetic control. Lancet 1978; ; : 732-5.

${ }^{4}$ Howe-Davies S, Holman RR, Phillips M, Turner RC. Home blood sampling for plasma glucose assay in control of diabetes. $\mathrm{Br} \mathrm{Med} \mathcal{F}$ 1978;ii:596-8.

(Accepted 15 November 1979)

\title{
Protective effect of inhaled salbutamol powder in children assessed by histamine challenge
}

\author{
C R PULLAN, A J MARTIN
}

\section{Summary and conclusions}

A double-blind placebo-controlled trial of 100,400 , and $800 \mu \mathrm{g}$ inhaled salbutamol powder was conducted on 12 children. The protective effect at 10 minutes, two hours, and four hours was assessed by histamine challenge. At 10 minutes there was good protection with all doses, but by four hours there was significant protection only with $800 \mu \mathrm{g}(\mathbf{p}<0.01)$. Salbutamol powder may need to be taken at least every four hours for complete protection. There was a dose-related effect with a single dose of up to $800 \mu \mathrm{g}$; increasing the dose increased the effect and duration of action.

Currently advertised dose regimens of salbutamol powder for children (200 $\mu$ g three or four times a day) are apparently submaximal. Histamine challenge is a satisfactory method of assessing the protective effect of a drug in asthmatic children.

\section{Introduction}

Inhaled salbutamol is well established as a valuable treatment of wheezing in children. ${ }^{1}$ Many young children have difficulty mastering the metered aerosol ${ }^{2}$ but can use a dry powder inhaler. ${ }^{3}$ Young children unable to use a metered aerosol who require inhaled salbutamol have had to use air compressors to drive nebulisers, which are both cumbersome and expensive.

Salbutamol powder is now available for use in an inhaler (Rotahaler, Allen and Hanburys). This effectively increases the forced expiratory volume in one second $\left(\mathrm{FEV}_{1}\right)$ in adults ${ }^{4}$ and children. ${ }^{6}$ The recommended prophylactic dose is $400 \mu \mathrm{g}$ for adults and $200 \mu \mathrm{g}$ for children three or four times a day. This dose, however, may produce submaximal responses in

\footnotetext{
Department of Child Health, Royal Victoria Infirmary, Newcastle upon Tyne NE1 4LP

C R PULLAN, MB, MRCP, senior registrar

A J MARTIN, MB, MRCP, senior registrar
}

children, ${ }^{6}$ and Hetzel and Clark ${ }^{5}$ reported increasing effect in adults with cumulative doses of up to $800 \mu \mathrm{g}$. Many children with asthma have intermittent wheezing with a normal $\mathrm{FEV}_{1}$ for much of the time. ${ }^{7}$ Hence testing a single dose of a drug and its effect on $\mathrm{FEV}_{1}$ can be done only on a few more severely affected children. In the other cases, however, episodes may still be frequent enough to warrant continuous treatment with salbutamol.

Histamine is a non-specific bronchoconstrictor in increased bronchial lability. ${ }^{8}{ }^{9}$ It is useful in assessing the protective effect of drugs, since the bronchoconstriction can be controlled and its effect is transient. ${ }^{10} \mathrm{We}$ decided to assess the protective effect of a single dose of salbutamol powder using inhaled histamine. The trial was approved by the local ethical committee.

\section{Subjects and methods}

Twelve children aged 6-13 years with episodic asthma were studied. All could perform satisfactory forced expiratory manoeuvres. Eleven had a baseline $\mathrm{FEV}_{1}$ of $70 \%$ or more of the predicted normal value on each day (normal values taken from Cogswell et $a l^{11}$ ). One boy had an $\mathrm{FEV}_{1}$ of $58 \%$ predicted on one day and between $70 \%$ and $90 \%$ on the other days. Only steroids were continued from 12 hours before the start of each study day until after the last histamine challenge of that day.

Histamine challenge-The histamine challenge procedure used was similar to that of Chai et al. ${ }^{12} \mathrm{FEV}_{1}$ was recorded on a Vitalograph. When consistent results were obtained the best of three was used as a baseline. Buffered histamine acid phosphate was used in roughly doubling concentrations from $0.03 \mathrm{mg} / \mathrm{ml}$ to $10 \mathrm{mg} / \mathrm{ml}$. Solutions were administered by facemask from a Bard Mini-Neb nebuliser driven by oxygen at $8 \mathrm{l} / \mathrm{min}$. Five inspiratory capacity breaths were taken first of diluent alone, and three minutes later the $\mathrm{FEV}_{1}$ was recorded. Provided there was no fall in $\mathrm{FEV}_{1}$ with the diluent this was repeated with increasing concentrations of histamine at fourminute intervals until the $\mathrm{FEV}_{1}$ had fallen by $20 \%$ or more. The test was then stopped. The concentration of histamine that would produce a $20 \%$ fall (provocation concentration $20 ; \mathrm{PC}_{20}$ ) was calculated from the dose-response curve. If the $\mathrm{FEV}_{1}$ did not fall by $20 \%$ with the top concentration $(10 \mathrm{mg} / \mathrm{ml})$ a $P_{20}$ was calculated by extrapolation up to $20 \mathrm{mg} / \mathrm{ml}$, but not beyond. 
Salbutamol powder trial-Each of the 12 children was studied on four separate days within two weeks. Salbutamol and placebo cartridges were administered by Rotahaler in the following combinations: (1) placebo + placebo, (2) placebo $+100 \mathrm{~kg}$, (3) placebo $+400 \mathrm{~kg}$, (4) $400 \mu \mathrm{g}+400 \mu \mathrm{g}$. Cartridges were given double-blind in an order determined by the Latin-square design. A baseline histamine challenge was carried out at 9 am each day and the $P_{20}$ established. The cartridges were given two hours later. Histamine challenge was repeated at 10 minutes, two hours, and four hours after administration of the cartridges and a new value for $\mathrm{PC}_{20}$ obtained. Pulse rate was taken before and 10 minutes after the cartridges were given.

Statistical-The increase from baseline of $\log _{10} \mathrm{PC}_{20}$ was calculated and significance of differences between doses estimated by paired $t$ tests.

\section{Results}

Eight children had a baseline $\mathrm{PC}_{20}$ that remained within three consecutive concentrations of histamine solution, but three children varied by four concentrations and one by five. There was no statistically significant difference between the mean baselines for all 12 children with each dose $(p>0 \cdot 2)$. During the day when placebo was given the $\mathrm{PC}_{20}$ with the baseline challenge was close to that of the last challenge of the day; 11 children varied by one concentration and one by two concentrations.

The figure shows the mean increase from baseline $\log _{10} \mathrm{PC}_{20}$ in all 12 children with each dose at each time. At 10 minutes all salbutamol

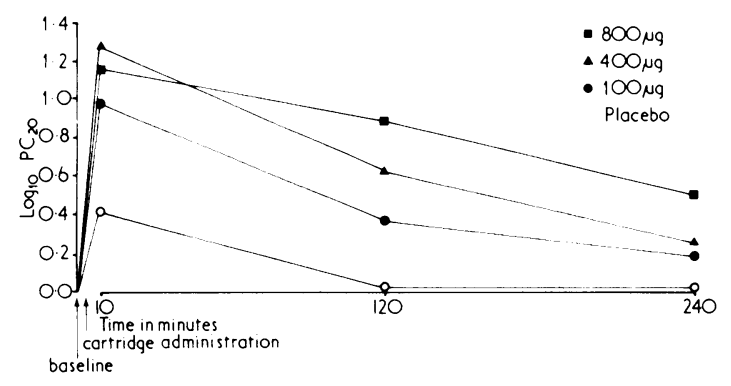

Increase from baseline of $\log _{10} \mathrm{PC}_{20}$ after inhalation of salbutamol and placebo powder.

doses gave significantly better protection than placebo $(100 \mu \mathrm{g} \mathrm{p}<0.05$; $400 \mu \mathrm{g} \mathrm{p}<0.005) ; 800 \mu \mathrm{g} \mathrm{p}<0.005)$. At two hours there was still significant protection with all doses $(100 \mu \mathrm{g} p<0.02 ; 400 \mu \mathrm{g} \mathrm{p}<0.005$; $800 \mu \mathrm{g} \mathrm{p}<0.005)$, but there was a trend for enhanced protection with higher doses $(100 \mu \mathrm{g} v 400 \mu \mathrm{g} \mathrm{p}>0 \cdot 2 ; 400 \mu \mathrm{g} v 800 \mu \mathrm{g} \mathrm{p}>0.01$; but $100 \mu \mathrm{g} v 800 \mu \mathrm{g} \mathrm{p}<0.02)$. By four hours there was no significant protection with $100 \mu \mathrm{g}(\mathrm{p}>0.02)$ or $400 \mu \mathrm{g}(\mathrm{p}>0.05)$, but there was with $800 \mu \mathrm{g}(\mathrm{p}<0.01)$.

The increase in mean pulse rate after placebo was 4.0 (range $\times 8$ to +16 ) beats $/ \mathrm{min}$, and after $100 \mathrm{~kg} \mathrm{3.5}$ (range $\times 12$ to +24 ) beats $/ \mathrm{min}$. Neither of these rises was significant. Mean pulse rate increased by $7 \cdot 4$ (range 0 to +24 ) beats $/$ min 10 minutes after $400 \mu \mathrm{g}$ salbutamol $(\mathrm{p}<0.05)$ and by 9.5 (range $\times 4$ to +24$)$ beats/min after $800 \mu \mathrm{g}$ $(\mathrm{p}<0 \cdot 05)$.

\section{Discussion}

Salbutamol dry powder effectively raised the threshold of sensitivity to histamine challenge. A pilot study on seven children showed significant difference between $200 \mu \mathrm{g}$ and $400 \mu \mathrm{g}$ at 30 minutes, three hours, and six hours, so $100 \mu \mathrm{g}$ was chosen to see if it was equally effective and $800 \mu \mathrm{g}$ to investigate the possibility of a greater effect with higher doses.

All doses of salbutamol gave satisfactory protection at 10 minutes. Some discrimination between the doses was lost because several children had a $\mathrm{PC}_{20}$ exceeding $20 \mathrm{mg} / \mathrm{ml}$, but all these were counted as $20 \mathrm{mg} / \mathrm{ml}$. There was a definite though small placebo response at 10 minutes, but this had disappeared at two hours. The benefit of the larger doses was seen in their duration of action. There was evidence of a dose-related effect, though the difference between only 100 and $800 \mu \mathrm{g}$ reached significance. By four hours only $800 \mu \mathrm{g}$ gave significant protection. This suggests that higher doses may benefit some children who get suboptimal or brief benefit from the standard dose. Although the mean pulse rate increased after 400 and $800 \mu \mathrm{g}$, this never caused concern and there were no subjective side effects. We have no information on side effects with regular use of higher doses.

Although some protection against histamine-induced bronchoconstriction remained at four hours with $800 \mu \mathrm{g}$, it was much reduced. Children who require regular treatment with salbutamol powder may need to take it at least every four hours.

Histamine challenge was well tolerated by all children. The fall in $\mathrm{FEV}_{1}$ was generally between $20 \%$ and $30 \%$, and any tightness in the chest was gone within 10-20 minutes. There was baseline variability, but there was no evidence of a cumulative effect or tolerance when histamine challenge was repeated every two hours. Sensitivity to histamine is consistent in adults over a short period ${ }^{8}$ but may vary with season ${ }^{13}$ and time of day. ${ }^{14}$ Histamine challenge therefore constituted a useful method of assessing the response of asthmatic children to the protective effect of a drug and its duration of action.

\section{References}

${ }^{1}$ Hambleton G, Shinebourne EA. Evaluation of the effects of isoprenaline and salbutamol aerosols on airways obstruction and pulse rate in children with asthma. Arch Dis Child 1970;45:766-8.

2 Saunders KB. Misuse of inhaled bronchodilator agents. $\mathrm{Br}$ Med $\mathcal{F}$ $1965 ; \mathrm{i}: 1037-8$.

${ }^{3}$ Paterson IC, Crompton GK. Use of pressurised aerosols by asthmatic patients. $B r M e d \mathcal{F} 1976 ; \mathrm{i}: 76-7$.

${ }^{4}$ Hartley JPR, Nogrady SG, Gibby OM, Seaton A. Bronchodilator effects of dry salbutamol powder administered by Rotahaler. $\mathrm{Br} f \mathrm{Clin}$ Pharmacol 1977;4:673-5.

${ }^{5}$ Hetzel MR, Clark TJH. Comparison of salbutamol Rotahaler with conventional pressurised aerosol. Clin Allergy 1977;7:563-8.

${ }^{6}$ Lenney W, Milner AD, Hiller EJ. Use of salbutamol powder in childhood asthma. Arch Dis Child 1978;53:958-61.

${ }^{7} \mathrm{McNicol} \mathrm{KN}$, Williams HE. Spectrum of asthma in children-I, clinical and physiological components. $\mathrm{Br} M e d \mathcal{F} 1973$; iv:7-11.

${ }^{8}$ Cockcroft DW, Killian DN, Mellon JJA, Hargreave FE. Bronchial reactivity to inhaled histamine: a method and clinical survey. Clin Allergy 1977;7: 235-43.

${ }^{9}$ Mellis CM, Levison H. Bronchial reactivity in cystic fibrosis. Pediatrics $1978 ; 61: 446-50$.

${ }^{10}$ Cockcroft DW, Killian DN, Mellon JJA, Hargreave FE. Protective effect of drugs on histamine-induced asthma. Thorax 1977;32:429-37.

11 Cogswell JJ, Hull D, Milner AD, Norman AP, Taylor B. Lung function in childhood. $B r \mathcal{F}$ Dis Chest $1975 ; 69: 40-50$.

${ }^{12}$ Chai H, Farr RS, Froelich LA, et al. Standardisation of bronchial inhalation challenge procedures. F Allergy Clin Immunol 1975;56:323-7.

${ }^{13}$ Itkin IH. Bronchial hypersensitivity to mecholyl and histamine in asthma subjects. F Allergy Clin Immunol 1967;40:245-56.

${ }_{14} \mathrm{De}$ Vries K, Goei JT, Booy-Noord H, Orie NGM. Changes during 24 hours in the lung function and histamine hyperreactivity. Int Arch Allergy Appl Immunol 1962;20:93-101.

(Accepted 20 November 1979)

ONE HUNDRED YEARS AGO M Georges Herbelin, a medical student at the Hôpital St Eugénie in Paris, was buried on Tuesday last with well-deserved honours. The young man, whose courageous devotion to the sick had won the admiration of the hospital authorities, caught diphtheria while tending a little girl suffering from that terrible malady. Before dying, the brave student had the satisfaction of receiving the Cross of the Legion of Honour, which was taken to him on his deathbed, and which he clasped to his breast as he expired. $M$ Lepère, Minister of the Interior, $M$ Herold, the Prefect of the Seine, several municipal councillors, and a number of leading physicians and medical students, attended the funeral. A detachment of infantry rendered him military honours. Several speeches by Professors of the Faculty were made over his grave. It is remarkable that the father of the deceased, who was a medical man, lost his life in the same way. (British Medical fournal, 1880.) 